\title{
Lighthouses or follies? Academies and New Labour's version of history
}

\begin{abstract}
This essay focuses attention on the UK government's Academies project, and more specifically on the claims that have been made for the project by its apologists. It contests the version of history that underpins these claims, challenging the notion that comprehensive schools amount to a failed experiment. Linked to the Academies programme is the goal of social mobility: this is critiqued both as an abandonment of long-standing commitments to social justice and as unrealisable through the pursuit of current policies.
\end{abstract}

There is a moment in Conan Doyle's "The Adventure of the Naval Treaty" (1893), when Holmes and Watson are on a train, travelling back up to London from Woking:
Holmes was sunk in profound thought and hardly opened his mouth until we had passed Clapham Junction.
"It's a very cheery thing to come into London by any of these lines which run high and allow you to look down upon the houses like this."
I thought he was joking, for the view was sordid enough, but he soon explained himself.
"Look at those big, isolated clumps of buildings rising up above the slates, like brick islands in a lead-coloured sea."
"The board-schools."
"Light-houses, my boy! Beacons of the future! Capsules with hundreds of bright little seeds in each, out of which will spring the wiser, better England of the future...."

The remarkable thing about this moment, as James Donald (1992) noted, is that it appears so unremarkable. Holmes's view of the board schools is not a product of his impossibly acute powers of perception; on the contrary, his words here attest to the strength of the post-1870 consensus, the commonsense understanding that education was too important to be left to the vagaries of the churches and the philanthropists.

In introducing to parliament the 1870 Elementary Education Act, the legislation that led, in effect, to Holmes's lighthouses, Forster set out precisely what the act was intended to achieve: "to bring elementary education within the reach of every English home, aye, and within the reach of those children who have no homes" (Maclure 1969: 104). He also provided a clear rationale:

Upon the speedy provision of elementary education depends our industrial prosperity. It is of no use trying to give technical teaching to our artisans without elementary education; uneducated labourers - and many of our labourers are utterly uneducated - are, for the most part, unskilled labourers, and if we leave our work-folk any longer unskilled, not withstanding their strong sinews and 
determined energy, they will become over-matched in the competition of the world. Upon this speedy provision depends also, I believe, the good, the safe working of our constitutional system. To its honour, Parliament has lately decided that England shall in future be governed by popular government. I am one of those who would not wait until the people were educated before I would trust them with political power ... but now that we have given them political power we must not wait any longer to give them education (Maclure 1969: 104-5).

For Forster, then, there were two imperatives behind the public provision of education, one economic and the other political: the need for a skilled workforce to enable the country to compete in the world market and the need, as Lowe put it, to "compel our masters to learn their letters" (Donald 1992: 18): universal schooling as the corollary of the extension of the right to vote. The nation's interests required coherent, public provision. The sign was there, emblazoned on the imposing front of each of these lighthouses, these beacons, the Victorian triple-deckers with their huge windows and airy, highceilinged classrooms that are still to be seen across the capital: LCC, or London County Council.

The last school I worked in was housed, partly, in just such a building, across the Thames from Clapham Junction. By the early twenty-first century, my classroom was beginning to show its age. The ceiling bore witness to a history of leaks in the roof; often, we had to pause in the middle of a lesson to move furniture and students away from the spot where a fresh cascade had appeared. The windows, a less than perfect fit, rattled alarmingly in the wind, were draughty in winter and in warmer weather could only be propped open, somewhat precariously, with a board rubber or a couple of dictionaries.

The first school I worked at, twenty years earlier, was a concrete and glass tower block, seven storeys high, in the East End of London. The foundation stone had been laid in the mid-1960s by Harold Wilson, the Labour Prime Minister then basking in the white heat of the technological revolution, to which, presumably, this purpose-built comprehensive was intended, in some small way, to contribute. My classroom, like almost all the classrooms throughout the school, was south-facing and lacked adequate blinds. When the sun shone, my students didn't so much bask as swelter, and their lethargy was not wholly attributable, I think, to the lack of pace in my lessons.

The tower block still stands, pretty much as it was when I arrived at the school in 1985, and pretty much as it had been, I imagine, when Harold Wilson opened the school. The Victorian triple-decker where I last taught, on the other hand, is no more, bulldozed, along with the hodgepodge of other buildings which made up school, and replaced with a smart new design, built under a PFI (Private Finance Initiative) contract by a Japanese multinational company. No LCC logo adorns its frontage. The comprehensive school continues, albeit rebranded as a "Business and Enterprise College," but the fate of the old Victorian building is emblematic of a profound change in the 
landscape of schooling, in London and, to differing degrees, in other parts of England.

Consensual for so long, public education - publicly financed and publicly accountable - is undergoing a series of strange mutations. I want to focus here on the academies project, to draw attention to the versions of history that its apologists have produced to justify their creation, and to suggest something of the curricular implications of this development.

Peter Hyman, Downing Street adviser turned classroom assistant, described the academies project thus:

Academies are one of Tony Blair's pet projects. They symbolise many of his aims for public services. They are state schools, independent from the LEA, with the freedom to innovate, with $£ 2 m$ sponsorship from an outside organisation - private, voluntary, foundation - matched by $£ 25$ to $£ 30 \mathrm{~m}$ from government. The best of them are spectacular new buildings, built by top architects. They are, to quote Tony, about 'excellence not mediocrity' (Hyman 2005: 306).

To understand what they represent is to understand a great deal about the orientation of New Labour's education policy; and to understand this requires an exploration of New Labour's version of the history of public education provision in this country.

Speaking at the opening of the Bexley Business Academy in South East London in 2002, Tony Blair signalled the significance of the moment, launching "business and enterprise as a new specialism with all its potential for motivating young people and enhancing the links between schools and employers." From their inception, the academies were not separable from a particular view of the relationship between education and business: they were part of the reconfiguration of schooling as preparation for the world of work. That is part of the point of the sponsor, to whom control of the school is handed: education, in New Labour's view, is safe in the hands of car salesmen. And it's no coincidence that over half of the academies opened by September 2007 had business and enterprise as one of their specialisms, though this proportion has diminished in the most recent batch (Curtis et al. 2008: 8; see also Beckett 2007).

For Blair, the new academy was "already becoming a beacon of hope and aspiration to the whole community" - a very different kind of beacon from the board schools:

... this $£ 31 \mathrm{~m}$ project symbolises so much that we are seeking to achieve across our education system nationwide through investment and reform - not just better facilities, but a wholly new and better way of delivering education, developing the potential and aspirations of each individual child. All the radical things about this academy - the independent sponsor; the business and 
enterprise specialism; the state-of-the-art facilities and use of IT; the reformed curriculum and ways of teaching and learning - none of these are ends in themselves. They are all means to an end the goal of developing each individual pupil in a tailored way, whatever their background.

The academies now opening are just one part of a fundamental change in Britain's comprehensive system. They are an extension of the specialist concept now accounting for half of all secondary schools in England. Taken together with greater flexibility in staffing, and the greater freedom for headteachers and governors to run their schools to deliver the best education they can, they are ending the 'one-size-fits-all' comprehensive system.

There is nothing standardised about this academy. Not its design; not its governing board; not its method of teaching; not its curriculum; not its facilities. It teaches children of all abilities but recognises that those abilities are different. It doesn't focus on children: it focuses on each child. That is where Britain's education system has to go. (The Business Academy Bexley website)

The Bexley Academy building, designed by Norman Foster, was indeed different from other schools. The central atrium, modelled on the floor of the Stock Exchange, announced a different relationship with capitalism: imitation replaced any suggestion of a critical perspective. And most of the classrooms, when I visited the school a year on, lacked a fourth wall, opening directly onto the echoing, cavernous central space of walkways and open plan areas. Daring and innovative though this was, it made both the acoustics and the management of the classrooms a nightmare. Now, as I understand it, most of the missing fourth walls have been instated. It's almost as if the school had been built without anyone feeling the need to consult anyone with any teaching experience. Perhaps such consultation might have led to the kind of standardisation that is anathema to New Labour; perhaps it might have smelt too much of "producer interest."

The way forward is illuminated by the lexicon of New Labour: it is the way of aspiration, flexibility and freedom, of novelty, change and reform; blocking the path lies the monolith of standardisation, or, as Blair wrote in a Fabian Society pamphlet published the same year, "the outdated mass production approach that too often characterised public services after 1945" (Blair 2002: 5). For Blair, the welfare state and the education service that emerged in the postwar years seems tinged with an East European greyness. The fundamental problem was that

... public services ... have not been reformed to deliver in a modern, consumer-focused fashion.

$\cdots$

We must recognise that what was absolutely right for a time of real austerity no longer meets the needs and the challenges in an age of growing prosperity and consumer demand (Blair 2002: 2, 3). 
We are all consumers now, apparently:

Choice is crucial both to individual empowerment and - by enabling the consumer to move to an alternative provider where dissatisfied - to quality of service (ibid.: 20).

Quite how this is meant to work within education seems less than entirely clear. Students moving from one class to another when they don't like their Maclessons? Or from one school to another if the Macteacher disappoints? That did seem to be what Blair had in mind. The growth of the specialist schools' movement would, he asserted, generate "more good secondary schools and a greater capacity to choose between schools" (2002: 29), while "we also need more choice within schools, particularly in the later secondary years as the talents and aspirations of pupils diverge" (ibid.).

What appears to be envisaged, then, is an education market regulated primarily by consumer choice. Even before the credit crunch, this was an unappealing prospect; now, when banks and multinational corporations beg for state recapitalisation, if not quite a thorough-going programme of nationalisation, the adherence to free-market values in any sphere of public life seems doctrinaire, to say the least. And the one choice which the education consumer is not permitted to make, it would seem, is to reject the imposition of an academy - a limitation that has been exposed by the numerous local campaigns against academies, campaigns that have united diverse groups of parents, teachers and governors (Hatcher and Jones 2006).

What I am trying to tease out is what the academies programme represents. What is the problem to which it is the answer, and what kind of answer is it? For the Blair government which launched the programme, academies were an extension of the specialist schools programme and, simultaneously, a breach with the past. The problem, in Blair's terms, was mediocrity, the uniformity of the comprehensive system, the complacency of a one-size-fits-all approach to education. The answer was thus to free up the system, to use the private sector to reinvigorate the public, to allow successful entrepreneurs to manage schools, so that, presumably, something of their entrepreneurial success would rub off on the students who passed through the gates of their academies. The problem, thus represented, involved a breathtaking rewriting of history, while the solution involved an equally audacious act of amnesia, together with a denial of the real continuities with previous (failed) education policy.

The big lie of the Blair education project is that the comprehensive system failed. The truth is that, as a national system, it was never tried. The 1870 act, like every subsequent piece of education legislation in this country, involved an accommodation with powerful interests, with the churches, who continued to exercise a significant, and significantly skewing, effect on public provision, and with the private sector, which has continued to operate outside the system, and on the most favourable terms (including, in the case of the elite independent schools, the benefits of really quite surreal charitable 
status). In some parts of the country, comprehensive reorganisation never happened; in other parts - even in Inner London - the different admissions procedures of voluntary aided schools ensured the perpetuation of structural inequalities. That was, of course, why in the early 1990s the Blairs could choose to send their children halfway across the capital to the highly exclusive London Oratory, rather than to Islington Green, the secondary school on their doorstep (which has now, despite a vigorous, long-running campaign of opposition, succumbed to its fate and become an academy).

Andrew Adonis, the policy architect and chief propagandist of the academies programme, presented a view of the fractured, unequal and class-ridden nature of education provision in his A Class Act: the myth of Britain's classless society (1997). For Adonis, though, the chief culprit in the perpetuation of class divisions was the "comprehensive revolution": it's a term he uses repeatedly, and it's an odd one, given the evidence he provides of a pattern of provision where the move towards comprehensive schools always sat uneasily in a mixed economy of privilege. Repeatedly, too, he asserts that

The comprehensive revolution has not removed the link between education and class but strengthened it (1997: 51).

The comprehensive revolution, tragically, destroyed much of the excellent without improving the rest. Comprehensive schools have largely replaced selection by ability with selection by class and house price (ibid., 55).

The tragic irony is that for all the good intentions, the destruction of the grammar school - in the name of equality of opportunity - only had the effect of reinforcing class divisions (ibid., 61).

What is bizarre about these assertions is that they ignore a mass of accumulated evidence about the success of even the partial reform that actually-existing comprehensive schools represented. As Caroline Benn and Clyde Chitty (1996) demonstrated, comprehensives were effective in raising standards of attainment. ${ }^{1}$ The New Labour programme is, in essence, an ideological programme, based not on evidence but on a priori commitments. Of course it is true that the education system has not produced social justice how could it, in a society which is so riven by inequality, and when it as a system has tended, as Adonis himself demonstrated, to reproduce these wider social inequalities? And of course it is true that it is possible to find teachers who accept failure as inevitable, an immutable consequence of deprivation or depravation or both: again, how could it be otherwise when the system in which they work is one in which inequality operates as a structuring principle? To blame teachers or comprehensive schools for these facts is rather like blaming anyone who has ever taken a bus for the parlous state of General Motors, or anyone who has ever opened a Post Office savings account for the collapse of Northern Rock and Lehman Brothers.

Does this mean, then, that what Adonis was masterminding, through the academies programme, was nothing short of a return to a grammar school 
system? The short answer is no. Some academies undoubtedly operate selective admissions procedures, whether overtly or covertly. And there is plenty of hard evidence about the readiness of academies to skew their outputs in other ways - such as the (il)liberal use of expulsion (Curtis et al., 2008). But the programme as a whole cannot be accurately represented as an attempt to turn back the clock. As Richard Hatcher (2008) has suggested, there are aspects of the academies programme that can more plausibly be linked to the government's drive to create a clearly defined "vocational" pathway in post-14 provision - and there is an obvious connection between this orientation and the totemic value of the sponsors, captains of industry who can both lead by example and, simultaneously, ensure the supply of an appropriately schooled workforce.

There is, though, a sense in which Adonis's idea of the grammar school really does provide the key to an understanding of what the academies programme represents. Stephen Ball suggests that the academy sponsors are to be seen as "hero entrepreneurs [who] embody the values of New Labour: the possibilities of meritocracy, of achieving individual success from modest beginnings, and wealth creation from innovation and knowledge" (Ball 2007: 175). What matters, then, is the possession of wealth: wealth is a signifier of individual merit; what is absent, occluded, is any sense of how such wealth might have been accumulated. New Labour education policy has thus created a monstrous fusion of Adam and Winston Smith, a forlorn character forever cheering himself up with the mantra that if there was hope it must lie in the captains of industry.

I taught for eleven years, in between my time in the Wilsonite tower block in the East End and the soon-to-be-bulldozed Victorian triple-decker, at a comprehensive school in Hackney. It no longer exists, razed to the ground and replaced by a shiny glass-and-concrete academy. The website of the new academy (whose motto is "traditional values in a modern world") announces:

Our approach can be summed up as: 'Entrepreneurial about learning; in the business of success.' ... Our patron, Jack Petchey, believes in an approach to life which says, 'If I think I can...I can!' So each student are expected to strive for the highest level of individual success (http://www.petcheyacademy.org.uk/academy/ethos-values.php, accessed 29 December 2008)

The slogans may enact a perfect fusion of market values and educational aspirations (even if the control of subject-verb agreement is less assured), but what this means in practice is less clear. The salient point is the totemic significance of Petchey himself, as role model and motivator. More details about the sponsor and his rise from East End barrow boy to multimillionaire car salesman and property tycoon are to be found on the website of the Jack Petchey Foundation. Most informative of all, though, in what it reveals about the academy's values and culture, is the section addressing the "economic wellbeing" strand of the Every Child Matters agenda: 


\section{Cashless Card System}

On Monday we will be starting our trial of the new and updated cashless cards. Two groups of students have been selected to take part in the trial. ... They were chosen for their regular high standards of lining up.

These students will be able to gain access to the toilets on Barts Orange and Barts Yellow. They will also be able to load money onto their accounts using the money loader.

We hope that this will encourage them to take more responsibility in managing their money and making sure that they are all in credit (http://www.petcheyacademy.org.uk/.php-23, accessed 29

December 2008).

Valuable lessons indeed - if only they could have been learnt by the directors of Lehman Brothers, or by Bernard Madoff.

In Adonis's version of history, the grammar school provided the means of achieving the meritocratic ideal - where success is the reward for talent and hard work. The corollary of the commitment to meritocracy is an interest not in social justice but in social mobility. What meritocracy does is to accept the status quo, to accept at a societal level the continued existence of structural inequalities, asymmetries of wealth and power, but to seek to ensure that capital, whether symbolic or actual, is distributed on the basis of individual worth rather than accidents of birth.

Gordon Brown's 2008 lecture to the Specialist Schools and Academies Trust was all about social mobility. "Mobility" occurs more than thirty times in the speech and it becomes the means whereby the past can be understood and the future planned for:

If you look back to the first big phase of post-war social mobility, it was brought about by fundamental changes in the occupational and industrial structure of the British economy. We saw the growth of new occupations and professions, the rise of a salaried middle class and a skilled working class. My generation was given opportunities their parents had never dreamed of - the chance to become teachers and doctors and engineers and civil servants for the first time because of the 1944 Education Act, secondary education guaranteed to all.

As the children of the 1950s became students in the 1960s, there were new grants for studies and new universities to study at. It was the generation of room at the top, the children of Butler's Education Act, of Bevan's Health Service, and of all the other reforms of the post-war social patriots (Brown 2008: np).

It is an incoherent history, and a very odd one. Is Brown attributing an increase in mobility to profound economic and social changes or to a legislative programme? Was the extension of secondary education the cause of increased social mobility or a symptom of it? Were medicine, teaching, engineering and the civil service equally accessible to those (the majority) of 
Brown's generation who spent the last years of schooling in secondary moderns? And was the primary motive of the Attlee government to increase social mobility? Is that really what the welfare state was for?

More perplexing still is Brown's use of the term "social patriots." It is a phrase with an interesting history, dating back to arguments during the 1914-18 War. Those who maintained a commitment to international solidarity used it as a term of abuse, directed against their former comrades who had become complicit in the conduct of the war - those who had abandoned class politics in favour of belligerent national(ist) politics (see, for example, Deutscher 1954: 232, Thatcher 2003: 73). The phrase has maintained some currency in the debates of the left - as Brown, the editor of The Red Paper on Scotland (1975), would have known - but it seems unlikely that Brown was expecting his audience at the Specialist Schools and Academies Trust to pick up on the allusion. The point in describing the post-war Labour government as social patriots in this context, where Brown is attempting to trace a line from the 1944 Education Act to the academies programme, is, presumably, to cast himself as the lineal inheritor of their social patriotism. It does make one wonder what kind of struggle, with whose version of history, is being conducted. Is this evidence of some terrible, contorted, guilt-ridden battle within the soul of the Glorious Leader - a moment when the unspeakable other of Britain's involvement in Iraq and Afghanistan emerges unbidden into the light?

In any event, the shadow passes and Brown goes on to outline the routes whereby the goal of social mobility will be attained - measures to do with the regulation of childcare and parenting, and then schooling. It is at this moment in the speech that Brown's sense of history seems to owe less to Marx or Lenin and rather more to Sellar and Yeatman's 1066 and All That (1930), as he shares his aspiration that Britain will once more become Top Nation:

The third route to greater social mobility is to give every child in Britain a world class education, putting our country at the top of the international education league table. That means every child mastering the basics in primary school, with more specialist English and maths teachers and more one to one tuition, such as Every Child a Reader.

It means no school achieving less than $30 \%$ of pupils getting five $A^{*}$ to $\mathrm{C}$ grades at GCSE, including English and maths, with more schools able to join together in federations. It means we will support the best head teachers to work in challenging schools. It means we will expand the academies programme to open 300 by 2010.

I happen to think that giving more individual attention to struggling readers in primary school is probably quite a good thing to do, and a reasonable use of public money. It diverts resources to where they are most needed, and may well prove to be an early intervention that is successful. Whether it will have China, India or Brazil quaking in their boots seems both less certain and less appropriate as a rationale for education policy. 
Once again, though, it is the staggering incoherence of what is proposed that is most apparent - a ragbag of different initiatives each of which begs more questions than it answers. The Public Accounts Committee was circumspect in its recent evaluation of the academies programme:

Academies are getting better GCSE results because they have had more money, new buildings and some of the best headteachers in the country, according a Commons report. But it questions whether improvements in results in the multi-billion pound programme will continue as the excitement in each new school wears off....

Regular state schools could do just as well with the same funding, it finds (Curtis \& Lipsett 2007).

Regular schools, though, particularly if they are regular schools that have fewer than 30 per cent of their intake achieving five GCSEs at grades $A^{*}-C$, have been on the receiving end not of academy-style funding largesse but of massively damaging publicity. The arbitrariness of the thirty per cent threshold for so-called National Challenge schools takes no account of local circumstances, no account of differing intakes or levels of student mobility. The effect has been to damage staff morale and student recruitment, and thus to put previously thriving schools into downward spirals from which the most obvious escape route is for the school to cease to exist and to be replaced by an academy.

But it is not just the means that are dubious; Brown's goal of social mobility just won't stand up to scrutiny. Before speaking to the Specialist Schools and Academies Trust, he would have been well advised to have read a sober, detailed and entirely convincing research report, commissioned and published by the Department for Work and Pensions, into Factors influencing social mobility (Nunn et al. 2007). The report indicates that there is "very little evidence in European countries ... to support the notion that social mobility is linked to economic growth" (2007: 26). And it makes the point that, though education might appear to be an important factor in social mobility:

there is considerable evidence that the introduction and expansion of universal education systems in the UK and Western Europe have not led to increasing levels of relative social mobility. This is due to a range of factors including the ability of middle-class families to take advantage of educational opportunities (Nunn et al. 2007: 3).

It might be reasonable to assume, then, that measures that increase the element of choice in education provision would exacerbate this tendency. The report also refers to evidence that "social class of origin influences individuals' choice of subject in a way which may have an impact on their employment prospects and thus, their social mobility" (Nunn et al. 2007: 45). The implication of this is that the development of separate pathways, particularly in 14-19 education, is likely further to restrict social mobility. If this were not enough, the report concludes that "social mobility appears to be remarkably 
resistant to policy initiatives designed to affect it" (Nunn et al. 2007: 70). So, to sum up its findings: Brown's emphasis on social mobility as an economic lever is misguided; his faith in education as a means whereby mobility can be achieved is not supported by any evidence; his linking of social mobility and social justice is unjustified.

There is also a fundamental incoherence in the programme. Somehow, rather like the putatively beneficial effects of trickledown capitalism, the gains made in an academy are supposed to improve results in surrounding schools. Quite how this effect is imagined is not clear. But then the whole conception of change that underpins the academies movement is not a coherent, systemic one. On the contrary, the impact is to increase inequalities.

So what is the promise of the academy for the individual child? Quite simply this: if you buy into the ethos, you accept the power of the institution and you conform to its rules and ways of doing things, you may be the recipient of some symbolic capital. The only agency that students and their families are afforded is one of consumer choice - applying to Academy A rather than Bog Standard Comprehensive B. Once across the threshold, it is all about what the academy can do to turn base metal into gold.

Ironically, then, the solution that the academies offer is one that also locates the history of failure squarely in school students, their families and communities. What the remedy offers is "developing each individual pupil in a tailored way, whatever their background" (Blair's words, quoted above): the force of those last three words is to consign to irrelevance at best, at worst the status of active impediment, the histories, cultures and experiences that school students bring to education:

Whereas the ideal of progressive education was a notion of individual development and self-realisation combined to a greater or lesser extent with an idea of collective emancipation, personalisation operates with more explicit norms; it is an attempt to identify the individual learning strategies that are most effective in reaching an externally given and predefined outcome. It does not involve a curriculum claiming to respond primarily to students' interests, nor a pedagogy that encourages children to 'be themselves'. On the contrary, it is based on offering support to individual students in order that they may reach defined targets. ... Above all, it means 'curriculum choice', particularly during the 14-19 stage, when academic and vocational pathways become available. At this point it becomes difficult to distinguish personalised learning from a form of selection, and the appeal to individual need folds into the reproduction of social divisions (Jones et al., 2008: 12223).

Personalisation, like Blair's insistence on the child, not children, as the proper focus of schooling, academy-style, amounts to a denial of larger transformative possibilities. How could it be otherwise when the aim of schooling, thus conceptualised, is the individual salvation of social mobility - 
and not the reformation of society that is entailed in the now-unfashionable commitment to social justice?

In this respect, of course, it would be a mistake to see this model of schooling as markedly different from Holmes's lighthouses, shining down on the leadcoloured sea of working-class London. And this model has clear consequences for curriculum in general and English in particular. It promotes a functional, not an emancipatory, view of the subject - and it leaves students' subjectivities out of the picture entirely. It leaves no room for dialogue, no room for local interests, no room for explorations of specific histories and cultures - no room, in other words, for the versions of English promoted by Harold Rosen that were celebrated in the last issue of this journal.

\section{References}

Adonis, A., \& Pollard, S. (1997) A Class Act: the myth of Britain's classless society, London, Hamish Hamilton.

Ball, S. J. (2007) Education plc: understanding private sector participation in public sector education, London \& New York, Routledge.

Beckett, F. (2007) The Great City Academy Fraud, London \& New York, Continuum.

Blair, A. (2002) The courage of our convictions: why reform of the public services is the route to social justice, London, Fabian Society.

Brown, J. G. (ed.) (1975) The Red Paper on Scotland, Edinburgh, EUSPB

Brown, G. (2008) The Specialist Schools and Academies Trust $12^{\text {th }}$ Annual Lecture, 23 June 2008, London, Specialist Schools and Academies Trust

Chitty, C., \& Benn, C. (1996) Thirty Years On: is comprehensive education alive and well or stuggling to survive? London, David Fulton.

Curtis, P., \& Lipsett, A. (2007) “Acaedmies' success may be short-lived, says report" Education Guardian, 18 October 2007

(http://www.guardian.co.uk/education/2007/oct/18/schools.newschools, accessed 1 September 2008).

Curtis, A., Exley, S., Sasia, A., Tough, S., \& Whitty, G. (2008), The Academies programme: Progress, problems and possibilities, London, Sutton Trust.

Deutscher, I. (1954) The prophet armed: Trotsky, 1879-1921, London, Oxford University Press.

Donald, J. (1992) Sentimental Education: Schooling, Popular Culture and the Regulation of Liberty, London, Verso.

Hatcher, R. (2008) "Academies and diplomas: two strategies for shaping the future workforce" Oxford Review of Education 34.6: 665-676.

Hatcher, R., \& Jones, Ken (2006) "Researching Resistance: campaigns against Academies in England." British Journal of Educational Studies 54.3: 329-351.

Hyman, P. (2005) 1 out of 10: from Downing Street vision to classroom reality, London, Vintage.

Jesson, D. (2008) "Grammar schools in the $21^{\text {st }}$ century and 'social mobility"” Research Intelligence, 105 (November 2008), pp. 24-25. 
Jones, K., Cunchillos, C., Hatcher, R., Hirtt, N., Innes, R., Johsua, S., \& Klausenitzer, J. (2008) Schooling in Western Europe: the New Order and its adversaries, Basingstoke \& New York, Palgrave MacMillan.

Maclure, J. S. (1969) Educational Documents: England and Wales 18161968, London, Methuen.

Nunn, A., Johnson, S., Monro, S., Bickerstaffe, T., \& Kelsey, S. (2007).

Factors influencing social mobility, Department for Work and Pensions, Leeds, HMSO.

Sellar, W.C., \& Yeatman, R.J. (1930) 1066 and All That, London, Methuen Thatcher, I.D. (2003) Trotsky, London \& New York, Routledge.

The Business Academy Bexley website,

http://www.tba.jazgen.com/tba/default.asp?id=0\&seq=10, accessed 28 August 2008

The Petchey Academy website, http://www.petcheyacademy.org.uk/.php-23, accessed 29 December 2008

The Jack Petchey Foundation, http://www.jackpetcheyfoundation.org.uk, accessed 29 December 2008. 
1 For further evidence of the role of grammar schools in reproducing social inequality, see Jesson (2008). 